\title{
Relasi Estetika dengan Kebenaran: Kajian Integrasi Teori Simetri Sains Fisika dan Al-Qur'an
}

\author{
Oleh: Afrizal Nur \\ Dosen Fakultas Ushuluddin UIN Suska Riau \\ Imansyah Putra \\ Guru SMA 1 Bangkinang
}

\begin{abstract}
Abstrak
Dalam artikel ini dijelaskan bagaimana kaitan antara kebenaran dan keindahan, tentunya keterkaitannya sangatlah erat dalam perkembangan sains modern, khususnya dalam kajian ilmu fisika. Bahasa keindahan itu dalam fisika diungkap dalam formulasi matematis teori grup dan ungkapan simetri-simetrinya. Ada sebuah ungkapan dalam fisika kontemporer bahwa hukum fisika didikte oleh simetri yang berati simetri yang merupakan bahasa keindahan dalam sains menentukan sebuah strategi bagi sains untuk merunut hukum baru yang lebih mempunyai skala aceptabilitas yang luas. Kenyataan ini memberikan sebuah pengayaan wacanan sangat luas bagaimana integrasi sains dan agama adalah sebuah keniscayaan penting, meningkat elemen penting yang sangat dihargai internalisasinya dalam agama adalah keindahan. Dalam kajian ini juga diberikan tinjauan soal konsep keindahan dalam Islam dan interelasinya yang erat dengan kebenaran. Oleh karena itu integrasi sains dan agama dapat dipandang sebagai sebuah jalan mencapai keindahan tertinggi yang berarti usaha mencapai
\end{abstract}


kebenaran tertinggi. Suatu hal yang merupakan bagian penting dari pandangan universal manusia.

Kata Kunci : Simetri, Keindahan, Tafsir

\section{RELASI KEINDAHAN DENGAN KEBENARAN}

Al-Qur'an menarik pandangan manusia kepada ciptaan-ciptaan Allah, khususnya penciptaan langit dan umumnya penciptaan seluruh makhluq yang lain. Allah mengajak manusia memikirkan ciptaanciptaan- Nya dan mengajarkan kepada kita tentang kesempurnaan penciptaan itu. Dalam hal ini Allah menantang kita untuk mengamati dengan seksama langit yang begitu kokoh; dan meyakinkan kita bahwa tidak akan kita menemukan kecacatan sedikitpun dalam ciptaan Allah; semuanya teratur dengan seimbang dan rapi. Cara Allah mengajarkan tanda-tanda kekuasaan-Nya sangatlah merangsang perhatian dan kesungguhan kita untuk mengamati penciptaan langit dan seluruh kejadian Allah yang lain. Pandangan yang tajam dan teliti inilah yang mau dirangsang oleh Allah. Pandangan bodoh yang biasa adalah menghilangkan keindahan alam yang cantik permai, halus, seni dan menakjubkan. Mata tidak pernah puas memandang keindahan. Hati tidak pernah puas menerima ilham-ilham Allah dan sarana-sarana dariNya. Aqal tidak pernah puas meneliti peratuan dan hukum yang berlaku di alam serta kehalusan dan kecanggihan peraturan alam itu. Orang yang memandang dengan mata yang tajam ini senantiasa hidup dalam tamasya (picnic) Ilahi yang gilang gemilang. Keindahannya tidak pernah buruk dan lusuh karena senantiasa menjadi baru pada pandangan mata, hati dan aqal.

Di dalam al-Qur'an term Keindahan di sebut dengan "al-Jamal", jamal memiliki ma’na keelokan yang banyak, kata jamal ini terulang didalam al-Quran sebanyak tiga kali yaitu surat Yusuf ayat 83 dan al-Nahal ayat 6 (Al-Asfahaniy, 2009 : 202), yang menjelaskan tentang 
keindahan dalam penciptaan "al-an'am” bahkan Sayyid Quthb sebagaimana dikutip Quraish Shihab mengomentari ayat ini dengan : ayat ini adalah gambaran pandangan al-Qur'an dan pandangan Islam tentang kehidupan. keindahan adalah unsur asasi dalam pandangan Islam itu dan bahwa nikmat bukan sekedar pemenuhan kebutuhan primer dalam bentuk makan dan minum dan mengendarai kendaraan, tetapi juga pemenuhan kerinduan yang melampaui kebutuhan pokok, yakni pemenuhan naluri keindahan serta perasaan gembira dan rasa kemanusiaan yang mengatasi kecenderungan dan kebutuhan binatang. (Quraish Shihab, 2009, 6: 534). namun ayat-ayat al-Qur'an yang menjelaskan tentang prinsip dan basis konsep metodologi keindahan sangatlah banyak didalam al-Qur'an, dan betapa kita meyakini ternyata al-Qur'an sangat merestui adanya keindahan, sebagai contoh adalah firman Allah swt dalam surat al-Mulk (67) 3-4 :

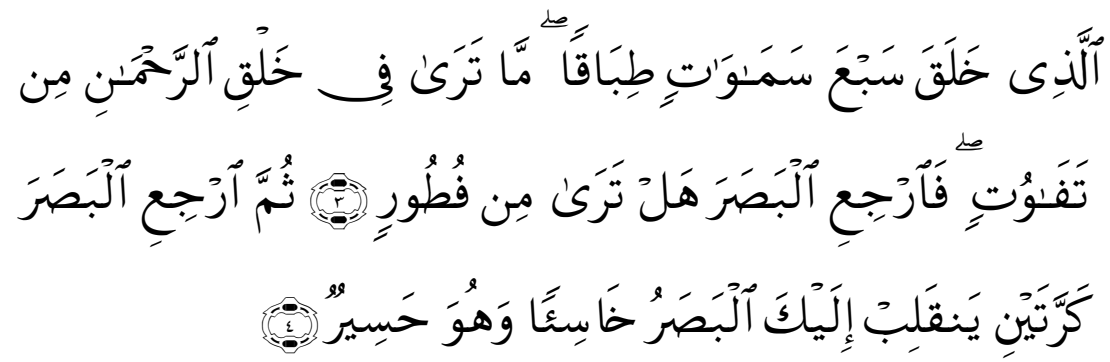

Artinya : Yang Telah menciptakan tujuh langit berlapis-lapis. kamu sekali-kali tidak melihat pada ciptaan Tuhan yang Maha Pemurah sesuatu yang tidak seimbang. Maka Lihatlah berulang-ulang, Adakah kamu lihat sesuatu yang tidak seimbang? Kemudian pandanglah sekali lagi niscaya penglihatanmu akan kembali kepadamu dengan tidak menemukan sesuatu cacat dan penglihatanmu itupun dalam keadaan payah.

Dalam ayat ini, Allah menciptakan langit berlapis-lapis atau bertingkat-tingkat. sebagiannya berada diatas yang lainnya, setiap langit itu seperti kubah untul yang lainnya Dalam penciptaan Allah terhadap langit tersebut, Allah SWT nyatakan tidaklah ada dalam 
penciptaannya tersebut kekurangan, cacat, saling bertentangan, justru sebaliknya ada keharmonisan dan keseimbangan pada penciptaannya (As-Shobuniy 3: 404). Kemudian Allah tanyakan, apakah ada sesuatu yang cacat atau retak di langit tersebut? Jawabannya tentu saja tidak. Kemudian Allah memerintah melihatnya sekali lagi (bahkan berulang kali), apakah ada yang cacat di langit itu? Hasilnya, jika dilihat berulang kali tidak ada cacat sama sekali pada ciptaan Allah tersebut. As-Shobuniy menafsirkan pengulangan aktivitas "al-Bashar" itu tidak terbatas dua kali tapi seringkali dan dalam ayat tersebut penglihatannya adalah penglihatan yang mendalam dan teliti (ibid), sebagai indikatornya adalah penglihatan itu menyebabkan keletihan dan rasa payah.

Syaikh As Sa'di mengatakan bahwa jika sama sekali di langit tersebut tidak ada cacat, maka ini menunjukkan sempurnanya hasil ciptaan Allah. Ciptaan Allah tersebut begitu seimbang dilihat dari berbagai sisi, yaitu dari warna, hakikatnya, dan ketinggiannya. Begitu pula pada ciptaan Allah lainnya seperti matahari, rembulan dan bintang yang bersinar. (As-Sa'diy, 1: 875)

Ada beberapa kata kunci yang hendak disorot dalam ayat ini, yaitu, خَلَقَ (menciptakan), تَفَوْتَ perbedaan, ketidak serupaan, disparitas, kontras dan ketidak harmonisan. kemudian artinya penglihatan, persepsi, penglihatan dalam, penglihatan, dengan pengetahuan, Al-Mirghani menafsirkan dengan melihat secara mendalam dan merenungi (al-Mirgani, 1996 : 69), kemudian artinya لَبَصَرَ rasa hina, tunduk, takluk dan rendah hati (humble), dan yang terakhir adalah جَسير artinya lelah, letih redup, tumpul, kabur, (Hans Wehr, A dictionary of Modern Written Arabic : 730).

Dalam artikel ini juga penulis mendatangkan hadits yang diriwayatkan imam Muslim disebutkan bahwa Allah swt adalah indah dan menyukai keindahan. Rasulullah shallalahu 'alaihi wa sallam bersabda, 


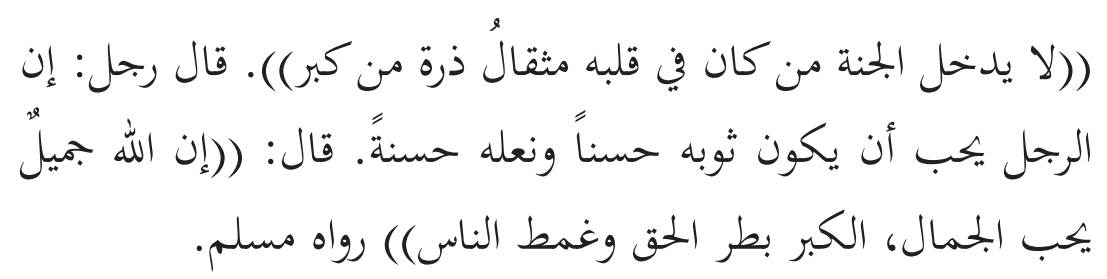

Artinya : Tidak akan masuk surga orang yang dalam hatinya ada kesombongan seberat biji debu”. Ada seorang yang bertanya: Sesungguhnya setiap orang suka (memakai) baju yang indah, dan alas kaki yang bagus, (apakah ini termasuk sombong?). Rasulullah shallalahu 'alaihi wa sallam bersabda, "Sesungguhnya Allah Maha Indah dan mencintai keindahan, kesombongan itu adalah menolak kebenaran dan merendahkan orang lain"

Imam an-Nawawi menjelaskan makna hadits di atas: " bahwa semua urusan Allah Ta'ala (maha) indah dan baik, dan Dia memiliki nama-nama yang maha indah serta sifat-sifat yang maha bagus dan sempurna" (Imam Nawawi 2 : 90)

Dari ungkapan di atas, nampaklah bahwa keindahan, keharmonisan, sangat terkait dengan keseimbangan, keserupaan dan perimbangan. Hal menarik yang hendak ditunjukkan dalam makalah ini bahwa ketiadaan disparitas dan keseimbangan adalah konsep yang sangat sentral dalam sains modern, khususnya fisika, yaitu konsep yang tertata dalam teori yang disebut sebagai teori simetri. sementara itu keindahan dalam Islam tercermin secara nyata dalam berbagai bentuk, diantaranya adalah arsitektur bangunan-bangunan Islam sampai dengan seni menulis atau dikenal dengan kaligrafi. Bangunan masjid yang megah di al-Hambra Cordova, serta pola-pola subtil kaligrafi indah yang terkadang melengkapi sebuah desain sebuah masjid yang indah. kalau kita mendalami lagi seni kaligrafi menurut penulis terinspirasi juga melalui ayat pertama surat al-Alaq yaitu tentang "Iqra" artinya bacalah, tentunya yang dibaca diantaranya adalah sesuatu yang tertulis yaitu al-Qur'an dan al-Qur'an tentunya lebih elok dan elegan jika ditulis dengan tulisan indah bahkan dengan kaligrafi. 
Bangunan-bangunan dari arsitektur Islam adalah cerminan dari usaha-usaha untuk melihat keindahan yang terungkap dalam pola geometri dan struktur. Pola-pola geometri dan struktur indah ini dicirikan oleh adanya simetri struktur yang tertata rapi. Sejalan dengan itu, selama 4000 tahun lebih usaha keras manusia dalam memahami misteri dan rahasia besar yang ada disekitar mereka, maka mereka menempuh berbagai startegi dan pendekatan. Akhirnya lahirlah ilmu pengetahuan, sains dan teknologi. Suatu hal yang memotivasi perenungan yang mendalam dan memunculkan pertanyaan bagaimana simetri memainkan peranannya yang luar biasa dalam pengembangan sains dan teknologi.

\section{PENGENALAN TEORI SIMETRI}

Perangkat yang paling berdaya yang pernah diciptakan manusia dan mampu mengungkapkan rahasia dunia paling renik justru adalah akselerator-akselerator partikel berukuran sangat besar. Dengan kata lain akselerator-akselerator ini adalah semacam mikroskop partikel, contohnya adalah Tevatron di Fermilab, Batavia, Illinois, Amerika Serikat. Tevatron mempercepat proton dan antiproton dalam arah berlawanan di lingkaran besarnya dan memberikan energi hingga 1 Milyar electron Volt. Partikel-partikel selanjutnya bertumbukan sempurna hingga quark dan antiquark yang ada di dalam proton dan anti proton ikut bertumbukan. Dengan meninjau hamburan tumbukan seperti ini, fisikawan mendapatkan semacam foto struktur materi untuk skala jarak terkecil yang pernah diselidiki (Rosen, 2008).

Dengan mengkaji skala jarak yang sangat kecil ini para fisikawan mulai mengerti bahwa gaya di alam sebenarnya berpadu yang mana di skala lebih besar tidak terlihat. Fisika modern menunjukan bahwa semua gaya fundamental di alam berpadu melalui suatu azas simetri yang sangat elegan yang dikenal sebagai invariansi Tera Lokal (Gauge Invariance Principle) yang keseluruhan strukturnya masih terus dikaji 
hingga hari ini.

Dengan ditemukannya simetri terpadu fisika ini, ilmu fisika telah melakukan lompatan konseptual hingga ke skala seperseribu milyar lebih kecil dari skala mikroskop terkuat yang pernah dibuat. Hal ini juga membantu kita untuk memahami seperti apa gerangan alam semesta ketika di $\frac{1}{10^{24}}$ detik. Dalam skala waktu sesingkat itu, teori yang dikenal sebagai teori gravitasi kuantum berperan dalam menjelaskannya, di mana teori ini sama sekali tidak intuitif yang menentang setiap gagasan sederhana kita soal ruang dan waktu. Karena begitu sulitnya membayangkan teori ini, para fisikawan memanfaatkan simetri sebagai pemandu dalam mendapatkan gambaran penyatuan lengkap semua gaya fundamental. Ide-ide barupun bermunculan menyangkut ini. Lahirlah teori-teori baru seperti teori adi dawai (superstring) dan teori-M. Teori-teori ini mengandung konsep dan prinsip simetri paling rumit yang pernah dipikirkan manusia. Dari uraian di atas kita telah melihat peranan sangat luarbiasa dari paradigma simetri dalam merunut hukum fundamental fisika kontemporer. ( El-Batanouny, 2008)

Dalam artikel ini, penulis mencoba meninjau sejumlah konsep penting fisika yang lebih sederhana karena peninjuan konsep simetri dalam fisika modern melibatkan sofistikasi matematika yang rumit dan membuat sulit untuk diafresiasi padahal yang hendak ditinjau adalah sisi keindahan dan kebenaran yang ditampilkan sains fisika dalam rangka merunut hukum fisika yang paling mendekati kebenaran. Dan itu bisa dicapai melalui tinjauan sederhana dalam beberapa konsep penting fisika dengan matematika sederhana. Harap diingat juga di sini, ketika dimaksudkan kebenaran dalam fisika, maka kebenaran di sini bukanlah kebenaran final sebagaimana yang menjadi concern dalam agama, namun adalah kebenaran tentative yang bergantung kepada uji coba eksperimen. Sebuah teori fisika yang benar adalah teori yang paling tahan uji coba eksperimen namun keterujian terus 
menerus tidak menjamin sebuah teori dipandang sebagai kebenaran yang final. Karena untuk merubuhkan sebuah teori cukup ditunjukkan satu eksperimen yang menegasikan nya.

Dalam ilmu fisika, secara sederhana simetri dapat dipandang sebagai simetri suatu system fisis adalah invariansi atau ketidak berubahannya tampilan suatu asfek fisis atau matematis oleh sebuah alih bentuk atau transformasi. Dalam pelajaran geometri sederhana waktu SD kita mengenal adanya simetri lipat, simetri putar, simetri cermin dari berbagai objek geometri. Sebagai contoh segitiga sama sisi mempunyai simetri lipat, simetri putar, simetri cermin, dan berbagai simetri yang lainnya. Serupa dengan hal itu, melalui sedikit abstraksi, fisika mengenal sejumlah simetri. Ditemukan kenyataan bahwa suatu hukum fisika mestilah mengandung simetri. Tidak ada hukum fisika yang benar-benar dipandang mewakili kinerja alam yang tidak mempunyai suatu simetri. Dalam bahasa matematika, jika suatu himpunan atau objek atau kumpulan persamaan matematika yang mendeskripsikan hukum alam, maka ia mempunyai grup simetri. Invariansi di sini maksudnya sifat tidak berubah. Oleh karena itu, melacak hukum fisika adalah ekuivalen dengan usaha mencari grup simetri yang lebih luas yang mendasari kerja hukum tersebut. Semakin luas suatu hukum alam yang memiliki terapan yang luas, rezim fisik yang luas, maka semakin rumit pola simetri yang hendak dicari, dan semakin tinggi kompleksitas grup simetri yang mendasarinya. Dan jelas usaha untuk mencari grup simetri ini melibatkan usaha pemikiran teoritis dan data eksperimental yang luas dan dalam, usaha terus menerus, sesuatu yang diterminologikan oleh al-Qur'an sebagai "lihatlah berulang-ulang, dengan insight yang mendalam".

Sebagai contoh sifat kelistrikan dan kemagnetan dipandu oleh grup simetri yang dikenal sebagai $U(1)$, sedangkan grup simetri yang membicarakan medan elektro kuat adalah grup SU(3), sedangkan grup simetri yang memandu medan elektro lemah adalah grup simetri 
SU(2). Untuk dikatehui di alam dikenal para fisikawan hanya ada 4 forsa alami fundamental, medan elektromagnetik, medan elektro kuat, medan elektro lemah. Terakhir medan gravitasi. Medan elektrokuat, elektro lemah dan elektromagnetik telah berhasil dicari grup simetri dari teori terpadunya yang dikenal sebagai model standard. Saat ini model standard adalah dekspripsi formal terbaik yang kita miliki yang menggambarkan secara lengkap interaksi partikel-partikel elementer di alam semesta. Grup simetri mereka adalah $\mathrm{U}(1) \times \mathrm{SU}(2) \times \mathrm{SU}(3)$. Hanya medan gravitasi yang tetap membandel yang menunjukkan usaha untuk menyatukan semua gaya itu adalah sebuah usaha yang membutuhkan "deep insight" lebih mendalam dan lebih melelahkan.

\section{(Rosen, 2008)}

Terkadang simetri alam mengalami sedikit cacat yang dikenal sebagai pengrusakan simetri (broken simetri) sebagai analogi lingkaran-lingkaran simetri pada lingkaran simetri pohon mengalami cacat, pola simetri pada sarang lebah sedikit cacat. Hal menarik terjadi juga pada fisika dimana pengrusakan simetri terkadang bisa mengindikasi perlunya dicari group simetri umum atau bisa meramalkan adanya mekanisme fisis baru yang luput dari tinjauan kita. Sebagai contoh hadiah nobel untuk fisikawan tahun 2014 Piter Higgs atas keberhasilannya meramalkan secara teoritis semua mekanisme yang dikenal dengan "Mekanisme Higgs" dan "Partikel Higgs", partikel yang dikenal sebagai "Good Partikel" itu ditemukan secara eksprimental oleh sebuah tim CERN Eropa. Kajian ini sangat luas mendalam dan sangat teknis, namun yang menjadi sorotan kita dalam makalah ini adalah bagaimana prinsip-prinsip keteraturan keseimbangan harmoni dan keindahan yang terungkap dalam bahasa teori simetri telah membantu fisikawan dalam mengendus dan melacak rahasia alam.

Salah seorang fisikawan legendaris Inggris yang bernama Paul Dirrac mengatakan : "jika kita harus memilih salah satu persamaan 
matematika yang mendiskripsikan hukum alam maka pilihlah persamaan yang paling indah dan elegan dan kita temukan alam semesta memang memilih persamaan yang paling indah dan elegan untuk menjadi hukum yang benar yang mendiskripsikan dirinya. Dari tinjauan sekilas bagaimana kinerja para fisikawan dalam menggali rahasia hukum alam terlihat jelas mereka dipandu oleh prinsip simetri keindahan dan keseimbangan. Prinsip-prinsip ini telah terangkum dalam ayat 3-4 surat al-Mulk yang kita paparkan diatas.

Penulis melihat bahwa agar usaha kita untuk mengintegrasikan sains dengan agama khususnya dalam penafsiran al-Qur'an yang bersifat saintifik menjadi berhasil maka usaha harus lebih kita tekankan pada pencarian dan prinsip-prinsip menggali hukum alam ketimbang kita terjebak dalam usaha mencari fakta-fakta sains yang ada dalam al-Qur'an, karena al- Qur'an bukanlah kitab sains, namun kitab yang memberi petunjuk upaya manusia mencapai kesempurnaan potensinya dimana salah satu wujud potensi itu adalah sains dan teknologi. Integrasi yang diharapkan hendaklah ditekankan pada upaya merumuskan metodologi-metodologi yang tepat dalam menggali rahasia alam dalam mengembangkan sains dan teknologi.

Namun tentunya juga harus berbeda dengan metodologi sains sekuler, maka diharapkan upaya dalam penggalian hukum alam ini akan menghasilkan suatu kualitas spiritual yang disebutkan oleh ayat diatas dengan istilah "Khasian". "Khasian" bukan dicapai dengan usaha yang pasif tetapi telah melewati fase yang melelahkan yang disebutkan dalam ayat 3-4 surat al-Mulk dengan term "HASIR" . Kajian yang berulang-ulang dan terus menerus yang melibatkan seluruh potensi akal budi manusia sopisikasi pemikiran teoritis dan upaya-upaya membangun infrastruktur fisik teknologi untuk bisa mengangkat pemikiran abstraksi teorotis ke wilayah uji ekspremental sehingga muara semua proses itu, maka akan melahirkan ilmuan-ilmuan yang memiliki ketakwaan, rendah hati dan terus berupaya menggali lebih 
dalam lagi. Ketika mereka berupaya menggali lebih dalam lagi, maka menjadikan kualitas spiritualnya semakin lebih baik lagi, ketundukan hati mereka akan semakin besar.

Sebagai contoh lainnya dalam prespektif ilmu fisika saat ini, visi sekuler memandang kegagalan para fisikawan untuk memadukan medan gravitasi dalam kesatuan teori gaya yang tunggal dengan tiga medan yang lain adalah sebuah situasi yang mereka pandang sebagai sebuah krisis meskipun menantang. Dalam metodologi sains Qur'ani situasi ini hanyalah suatu fase "al-Hasir" atau kelelahan yang tetap memiliki makna penting dalam pengembangan sains dan teknologi lebih dalam dan serius lagi, karena sasaran utama penggalian sains dalam al-Qur'an adalah kondisi "Khasi'un" yaitu ketaqwaan manusianya, bukan menggali rahasia alam semesta. Sehingga semua tahap proses penggalian sains dan teknologi memiliki nilai dan makna yang sama yaitu spritualitas manusia. dan tujuan terakhirnya adalah Tauhid. Tauhid sebagai puncak evolusi perkembangan sains dengan mudah dapat kita lihat dari sejarah sains fisika sendiri yaitu dari usahausaha para fisikawan yang terus mencari teori medan terpadu yang menjelaskan seluruh aspek alam semesta.

\section{KESIMPULAN}

1. Tinjauan terhadap sains fisika dan cara para ilmuan fisika dalam menggali hukum alam terlihat bahwa mereka dipandu oleh suatu paradigm yaitu simetri dan keindahan dan Paradigma ini ternyata telah ditunjukkan di dalam al-Qur'an

2. Kenyataan yang dipaparkan dalam artikel ini menunjukkan bahwa wacana integrasi sains dan agama sebaiknya lebih diupayakan pada usaha-usaha menggali prinsip.

3. Prinsip dan metodologi sains ketimbang hanya sekedar usahausaha fakta sains didalam al-Qur'an dan Sunnah 


\section{DAFTAR PUSTAKA}

Ach Maimun Syamsuddin, Integrasi Multidimensi Agama dan Sains, Ircisod, Jogjakarta, 2012

Al-Raghib Al-Asfahaniy, Mufradat Al-Fadzul Qur'an, Darel Qalam, Damaskus, 2009

Agus Purwanto, Ayat-ayat Semesta Sisi-sisi al-Quran yang terlupakan, Mizan, Bandung, 2008

Bruno Guiderdoni, Membaca alam membaca ayat, Mizan, Bandung, 2004

Wehr, Hans, A Dictionary of modern written Arabic, Library du Liban Beirut, 1961

Syaikh 'Abdurrahman bin Nashir As Sa'di, Taisir Al Karimir Rohman, Muassasah Ar Risalah, cetakan pertama, $1420 \mathrm{H}$.

Mehdi Gholsani, Filsafat Sains Menurut Al-Qur'an, Mizan, Bandung, 2003

Paul Davies, Membaca Pikiran Tuhan, Pustaka Pelajar, 1993.

Umar Juoro, Kebenaran Al-Quran dalam Sains Persandingan Wahyu dan Teori Fisika tentang Alam semesta, Cidesino, 2011

Imam Nawawi, Syarah Sahih Muslim, Darul Hadits Kairo jilid 2 : 90) 1994

M. Quraish Shihab, Tafsir Al-Mishbah, Lentera Hati, Jakarta, 2009

Wan Mohd Nor Wan Daud, Filsafat dan Praktik Pendidikan Islam Syed Naquib Al-Attas, Mizan, Bandung, 1996

Rosen joe, Symmetry Rules How Science and Nature Are Founded on Symetry, Spinger, Verlag Berlin Heidelberg, 2008

El-Batanouny M, Symmetry and Condensed Matter Physics A Computational Approach, Cambridge, New York, 2008 